\title{
CHANGING WORK PATTERNS OF THE SKOLT SÁMI
}

\author{
PANU ITKONEN \\ Postdoctoral Researcher \\ Arctic Centre \\ University of Lapland \\ Box 122, Rovaniemi 96101, Finland \\ e-mail: panu.itkonen@ulapland.fi
}

\begin{abstract}
This article explores changing work patterns in the Skolt Sámi reindeer herding community of Sevettijärvi, northern Finland. As a result of the Second World War, Finland lost the original home territory of the Skolt Sámi to the Soviet Union. The Skolt Sámi of the old Suenjel village moved to the Sevettijärvi area in Finland. In this article I present major changes in three areas of this group's work patterns: 1) combinations of livelihood; 2) forms of cooperation and reciprocity; 3) social constructions of work situations. The main causes of cultural change in the reindeer herding community have been the mechanisation of reindeer herding and the centralisation of reindeer ownership. In anthropological studies, traditional forms of behaviour have at times been seen as obstacles to economic development. My argument is different: traditional forms of culture - in this case forms of reciprocity - can increase possibilities for economic development. The research data shows that the centralisation of reindeer ownership has decreased the possibilities for economic development in additional forms of livelihood among Skolt Sámi reindeer herders. The number of herders has decreased and the entrepreneurial collaboration is arranged so that there is less and less traditional reciprocity between separate households.
\end{abstract}

KEYWORDS: Skolt Sámi • Sámi • reindeer herding • reciprocity • work • state

\section{INTRODUCTION}

This article reveals the changing work patterns of the Skolt Sámi reindeer herding community in Sevettijärvi, northern Finland. It is based on my social and cultural anthropology doctorate thesis Skolt Sámi Cooperation (Itkonen 2012) and its follow-up studies. The main research problem is the following: How have work patterns changed in the Skolt Sámi reindeer herding community of Sevettijärvi since the Second World War? I present major changes in three areas of work patterns: 1) combinations of livelihood; 2) forms of cooperation and reciprocity; 3) social constructions of work situations. The main factors behind cultural changes in the reindeer herding community have been the mechanisation of reindeer herding and the centralisation of reindeer ownership. 
In order to trace long-term cultural change among Sevettijärvi reindeer herders since the Second World War I use data from earlier anthropological studies of the Skolt Sámi reindeer herders, and statistical accounts. Analysis of current work patterns relies heavily on the 15-month fieldwork period of my dissertation. During that time, I lived in Sevettijärvi and took part in work activities relating to reindeer herding and additional forms of livelihood as well as conducting interviews with members of the work community. In exploring the central themes of my study I have combined qualitative and quantitative methods. One of the early findings of my study was the strong influence of state policies on reindeer herding since the state implemented its new structural subsidy policy in the early stages of the 21 st century. The objective of the policy was to centralise reindeer ownership in the hands of ever fewer reindeer herders. This notion soon became an inevitable part of my study in addition to my initial interest in reindeer herders' forms of collaboration. Since the fieldwork period I have visited Sevettijärvi at least once a year making further observations and conducting interviews among the reindeer herders. These follow-up explorations have made it possible to track down short-term structural changes over more than ten years.

As historical background it can be noted that Skolt Sámi communities have undergone fundamental changes over the last few centuries and over the last few decades. The original living grounds of the Skolt Sámi are now split by the borders of three countries: Russia, Finland and Norway. As a result of the Second World War, Finland lost Petsamo, the old Skolt Sámi home territory, to the Soviet Union, and most of the Skolt Sámi of the old Suenjel village moved to Inari municipality's Sevettijärvi area in northern Finland, which used to belong partly to old areas of the ancient Skolt Sámi village Njauddam, whereas most inhabitants of old Peaccam and Paacjok villages moved to more southern parts of Inari municipality. Today these communities are important carriers of Skolt Sámi culture. (Linkola and Linkola 2000: 9-11, 17)

After the historical splits above, the division of Skolt Sámi has continued in Sevettijärvi. During the last five decades, two factors have advanced their social and cultural fragmentation. In the middle of the 1960s, the so-called Snowmobile Revolution increased reindeer herders' dependence on machines, and increasing costs forced many reindeer herders out of this life (Pelto 1973: 116, 132-134). Similar changes occurred with Sámi reindeer herders in other Nordic countries and on the Kola Peninsula. The changes in Sámi reindeer herding in Nordic countries have been characterised as transformations from intensive to extensive reindeer herding. This means that reindeer herders spend less time on herding activities than before. (Beach 1981: 34) Extensive reindeer herding is one reason behind reindeer herders' increasing dependency on national economy (Ingold 1976: 43). It seems that the perspective of national economy has prevailed in local welfare and self-determination issues in reindeer herding (see Bennet 1988: 1-2). Robert Paine (1994: 20, 103, 107), who studied Sámi reindeer herders in Norway, made a distinction between reindeer herding and reindeer husbandry. Reindeer herding is about the economy of labour where reindeer herders work and make decisions together. Herding also takes care of the welfare of reindeer. Reindeer husbandry entails an allocation of capital and is interested in profit as the concern of a single family. Reindeer husbandry treats reindeer as a resource that reindeer owners harvest. Decisions relating to herding are made in herding groups, while decisions relating to husbandry are made within families. The ideas of possession and production 
encourage reindeer herders to own as many animals as possible. On the Kola Peninsula (of the Soviet Union, and today's Russia), the mechanisation of reindeer herding took place in a system where state organisations own the majority of reindeer while Sámi and other reindeer herders own only a minor portion of them (Pennanen 2000: 44-45). The studies mentioned above have described economic and structural changes among Sámi reindeer herders. Several collected systematic empirical evidence during a certain era, like Pertti J. Pelto's (1973: 119) studies in which the structures of reindeer ownership were analysed in 1958 and in 1971.

Shortly after Finland became a member of the European Union in 1995 the state's structural policy of reindeer herding started to divide members of the Sevettijärvi reindeer herding community into owners of larger individual reindeer herds, subsidised by the state, and smaller owners (under 80 reindeer) who do not receive subsidies. The state's subsidy policy has supported the centralisation of reindeer ownership despite $85 \%$ of Sevettijärvi reindeer herders objecting to this policy shortly after its implementation. (Itkonen 2012: 214)

A few earlier studies focused on the relationship between reindeer herders and the state in Nordic countries. Reindeer herders and state officials have had different opinions about the condition of reindeer pastures in Norway (Björklund 1990: 76). In Finland, the power holders have always been geographically far from the reindeer herders (Ingold 1976: 251) and the influence of the shrinking group of reindeer herders has diminished in official decision-making (Ruotsala 2002: 405-412). Furthermore, reindeer herders have been subordinated to European Union guidelines (Lenstra 1998: 352).

In Sweden, the rationalizing away of reindeer herders has belonged to threats of extensive reindeer herding where increases of herders' living standard have been based on increases in the number of reindeer per family. In this kind of approach, traditional forms of behaviour have been seen as obstacles to economic development. (Beach 1981: 295) In other words, it has been claimed that certain features of traditional Sámi reindeer herding and Sámi culture would not be economically rational in the modern world, and in this way culture and economy have been placed in opposition to each other. However, my studies have led me to another conclusion. I claim that traditional forms of culture could increase the possibilities for economic development among the Skolt Sámi if they are connected with more modern aspects of culture.

I want to continue the research tradition in which the study of change relies on empirical data from different points in time, something that has not been done with the Skolt Sámi reindeer herding community since the 1970s. My contribution to studies of Sámi reindeer herding lies in analysing work patterns and the structures underpinning them. I take a step on from earlier studies of Sámi reindeer herders by focusing on forms of collaboration and reciprocity. These issues have been noted in previous studies, for example those concerning reindeer herders in Siberia (Ventsel 2005: 42, 181, 186). However, my study develops a new model of reciprocity based on Marshall Sahlins's (2004 [1972]) scheme of reciprocity. Some of the Skolt Sámi reindeer herders' work patterns have transformed remarkably as a result of the centralisation of reindeer ownership. Traditional dimensions of reciprocity have given way to more modern aspects. The traditional forms of collaboration and reciprocity have served as generators of new activities in the past, although in today's conditions they seem to diminish and lose their strength. 
The number of reindeer herding households has fallen gradually among the Skolt Sámi. In 1938 in the old Suenjel village, 100\% of the Skolt Sámi population (210 people) used reindeer as a source of livelihood, with that percentage still at 100 in 1951 in their new home area Sevettijärvi. However, by 2002 the number of reindeer herding households in Sevettijärvi had dropped so that only $25 \%$ of the 220 Skolt Sámi were involved in reindeer herding.

The division of reindeer ownership was the following in the Sevettijärvi Skolt Sámi reindeer herding community in 2002: There were 2 large owner households with more than 400 reindeer, 6 upper medium size households with 225-400 reindeer, 15 lower medium size households with 80-224 reindeer, and 18 small households with less than 80 reindeer, altogether 41 active reindeer herding households.

In 2002, reindeer herders still practiced a variety of additional forms of livelihood giving a richness to their combinations of livelihood. In their ancient form of living in old Suenjel village, they used to combine different nature-bound forms of livelihood such as fishing, reindeer herding, hunting, and gathering. In modern Sevettijärvi, the traditional Skolt Sámi idea of combining several forms of livelihood took new forms. There were round 30 additional sources of livelihood, with most herders having more than one such source. Several businesses had been development among medium size reindeer owners before 2002. For example, in the local meat processing firm, three reindeer herders were able to increase the value of their products considerably. Reindeer herders' other additional forms of entrepreneurship were included the following: restaurant services, tourist accommodation, nature guide services, reindeer tourist services, carpentry, handicrafts, and forestry. There were also several forms of additional wage labour, such as work in the state owned Forest Care and Park Services, teaching in the local school, cleaning, construction of houses, road construction, and slaughtering. In addition, reindeer herders also practiced traditional forms of self-sufficiency, such as fishing, hunting and berry gathering.

Since 2002 the number of additional sources of livelihood has diminished as has their economic meaning among reindeer herders. Several additional forms of entrepreneurship have disappeared or declined, although tourist accommodation has survived fairly well as an additional income source.

The development of additional forms of livelihood has been minimal among Sevettijärvi reindeer herders since 2002. In the past, the developers were usually middle size reindeer owners who often had experience of other fields and who could not get by solely with reindeer herding. As the sizes of personal reindeer herds have grown, the interest in additional forms of livelihood has decreased. Not to mention other obstacles, like the lack of time, the lack of suitable co-developers and work force, and lack of experience and schooling outside reindeer herding.

The state's economic policy follows the ideals of the large-scale food industry, where reindeer herders are mainly providers of raw material. The key principle of this industry is profitability based on the growth of the unit size, i.e. the number of individually owned reindeer. In addition, some increases in efficiency can be expected through the use of new technology. However, this is a limited version of economic thinking that stresses only short-term profitability and the production of raw materials. It seems 
that this focus on profitability has superseded local level economic development. If the economy is supposed to develop well, there should also be development in activities other than the production of basic agricultural products (Begg et al. 2005 [1984]: 524). The ownership of reindeer combined with additional forms of production would give an advantage to the Skolt Sámi in comparison to entrepreneurs in other areas (see Wonnacot and Wonnacot 1990 [1979]: 41-42) because the Skolt Sámi can make use of reindeer and their own culture in many different ways.

Most of the development efforts relating to additional forms of livelihood have been centred in the nuclear families of reindeer herders. Such development units tend to be hierarchical in their organisation. There has been less development effort towards egalitarian cooperation between separate households, although the local meat production firm is one good example of egalitarian collaboration and reciprocity relations.

In the community of reindeer herders, there was a similarity between work groups in different work situations. Work groups that had developed additional businesses were fairly similar to work groups that were used in reindeer separations, i.e. work situations where the reindeer to be slaughtered were separated from those reindeer that were to be kept. The core structures of these situations were similar, i.e. the same people were key actors in both groups and the groups were based on similar kinds of cooperation and reciprocity. The development of the local meat production firm, for instance, was based on traditional egalitarian reciprocity and collaboration between three reindeer herders, and in reindeer separations the same men worked side by side the same way.

As sizes of personal reindeer herds have grown, hierarchical work groups within nuclear families have become more common in reindeer separations and the egalitarian work groups previously present in many reindeer herder households have declined. At the same time, the potential for reindeer herders to maintain or develop additional business lines with several households combining their efforts on an equal basis has declined. Nuclear family work groups have not had it much easier in this respect. At least, they have not developed considerable additional businesses recently.

In the old Skolt Sámi tradition, each family worked hard in several fields: reindeer herding, fishing, hunting, gathering, sheep husbandry, handicrafts, and building projects. Some of these forms of livelihood were practiced within nuclear families while some required collaboration and reciprocity across family borders. The old Skolt Sámi community was fairly egalitarian. Everyone had the money to get by and weaker members of the community were helped. (Linkola and Linkola 2000: 11) This kind of tradition, with strong social cohesion, would also support economic development in modern conditions. However, today's society stresses individuality and competition, modern ideals that have had an effect on the Skolt Sámi as well.

According to my study of the Skolt Sámi reindeer herding community of Sevettijärvi, cooperation and reciprocity were essential constituents of production and culture. Cooperation refers to forms of action, whereas reciprocities characterise relationships between individuals. Sahlins's (2004 [1972]: 193-195) model of reciprocity formed the basis for the analysis, although this model was modified somewhat as a result of my investigation. A new category in the scheme is 'neutral reciprocity', in which people do not interact with each other even though they can be in the same place at the same time.

I found altogether 19 positive forms of cooperation and reciprocity among the reindeer herders, a high number compared to modern work organisations. Apart from the 
positive forms there were three neutral and seven negative forms of cooperation and reciprocity - in total 29 forms of cooperation and reciprocity. The positive forms of reciprocity are divided into two parts, generalised and balanced. A specific form of generalised reciprocity, i.e. free help or 'cultural help', is given to a member of the community with the expectation that someone will help the giver when he or she is in need. In this case, the community serves as a kind of help bank. Among other forms of generalised reciprocity are house building bees and helping someone in the wilderness after an accident. A collective version of free help, i.e. generalised reciprocity, can be seen when a group of reindeer owners chase reindeer into a smaller enclosure in reindeer separations. Here the reindeer of owners who are not present are also taken care of, without any compensation, supporting 'we-attitudes'. The social dimension, the social price, is often reciprocity. As part of the activity of reindeer herding, the economic benefits of balanced reciprocities rely mainly on sales of reindeer carcasses. Balanced reciprocity takes place for example in work groups that deal with the handling of reindeer. In these groups, people compensate others for received services with similar services, or with other forms of compensation. When people in the work group belong to the same nuclear family, they usually work for the good of the family and receive their benefit through family arrangements. Neutral reciprocity describes situations in which people do not interact with each other. Neutrality means that they can concentrate on their tasks without disturbing others. The absence of positive and neutral reciprocity can lead to negative reciprocity, for example harsh competition and unfair treatment.

In the social construction of work situations, the meaning of kinship has diminished somewhat over the last five decades and the role of friendship as a basis for cooperation has increased. Relations between neighbours have lost some of their importance, while in reindeer herding families the professional role of women has become more central. Women can be organisers of family businesses or they can have jobs. However, women stand a little outside the core of reindeer herding, which is for the most part dominated by men.

The social construction of certain work situations has changed considerably since 2002. The work units of reindeer separations have become ever more controlled by single households, and they have become more and more dependent on their own work force. Their reciprocity relations to fellow reindeer herders have declined or disappeared, for example in certain phases of reindeer separations. New people from outside the traditional reindeer herding community of Sevettijärvi have stepped in to certain work situations in the reindeer herding community as the number of reindeer owners has reduced.

The changes in the social construction of reindeer herders' work have had an effect on their culture. The old community coherence was based mainly on cooperation and reciprocity between reindeer herders, most of whom had Skolt Sámi roots. Today, the reindeer are still owned mainly by the Skolt Sámi, who perform many of the core activities of reindeer herding. However, the number of Finnish collaborators has increased in certain situations, in addition to which some other Sámi people, and foreigners, have participated in certain activities. The community of reindeer herders has opened up lately bringing a new type of coherence to the community that exists alongside the old Skolt Sámi coherence. In this new social dimension, the role of Finns, other Sámi, and foreigners is important. 
My main research problem was to establish how work patterns have changed in the Skolt Sámi reindeer herding community of Sevettijärvi since the Second World War. I have presented data on three different dimensions of work patterns: 1 ) the combinations of livelihood; 2) the form of cooperation and reciprocity; and 3) the social construction of work situations. The decrease in reindeer herders' combinations of livelihood, i.e. the reduction in additional forms of livelihood, led me to questions of economic development. I argue that the state has not paid enough attention to the economic development of local traditional communities in its large-scale industrial policy. State policy has been one key factor in the change of work patterns. The other is the implementation of new technology.

The research data shows that the centralisation of reindeer ownership has reduced possibilities for economic development in additional forms of livelihood among the Skolt Sámi reindeer herders. Additional forms of livelihood have been central in the economic development of Skolt Sámi in Sevettijärvi. As the number of reindeer owners has decreased, the herders have to concentrate more on reindeer herding as their main form of livelihood. They no longer have the need for, or the interest in developing, additional activities, in addition to which there are not enough people in the reindeer herding community for development efforts. I claim that current large-scale industrialised reindeer herding is based on limited economic reasoning, and furthermore that it weakens Skolt Sámi culture, including its economy. If economic development relies solely on basic agricultural production without the refinement of products, it is very limited. Distant food production plants mainly focus on the processing of reindeer meat, while reindeer herders themselves are to a great extent producers only of raw meat. As part of the production process, the value of reindeer meat increases considerably, although benefits like this are felt mainly in the southern centres rather than in the local Skolt Sámi reindeer herding community of Sevettijärvi. A similar centralising process took place previously in agriculture. The state has advanced industrial food production as part of the economy. However, what might seem to be development from the viewpoint of the national economy turns out to be the opposite from the local point of view. In addition to food production, reindeer herding can also serve other fields of economic activity, for instance tourism, although this requires many, rather than few, reindeer owners.

As the number of reindeer owners has decreased, some traditional forms of cooperation and reciprocity have diminished. For example, balanced reciprocity work groups (such as those dealing with reindeer separation) have declined to include people from different reindeer herding households and instead maintain equality-based relations between group members. In traditional forms of balanced of reciprocity, people do not calculate their benefits. This type of attitude is needed in the development of new businesses. Today, the few development efforts made by reindeer herders come mainly in nuclear families rather than as the collaborative efforts of several separate households of reindeer herders. Many forms of free help, i.e. generalised reciprocity, still exist among Skolt Sámi reindeer herders. Collaborative free help is offered in reindeer separations to those who are not able to participate in the activity. House building bees still take place every now and then, although not as frequently as before. 
The social construction of Skolt Sámi house building bees has changed over the years. In the 1950s and 1960s those who volunteered to help with construction were for the most part relatives of the builder, i.e. other Skolt Sámi people. Today the variety of helpers is larger. Apart from the herder's relatives there are ever more other locals, and visitors, often Finns. Similar change can be seen in work groups for reindeer separations, where Finns and representatives of other nationalities have become more common as assistant workers when the number of Skolt Sámi reindeer owners decreased. We may say that Skolt Sámi reindeer herders' contacts with other people have become ever more significant in certain work situations.

I have analysed Skolt Sámi combinations of livelihood and forms of reciprocity in terms of economic development, and I have claimed that livelihood combinations and traditional forms of reciprocity have been good for reindeer herders' economies in modern conditions. However, I did not emphasise that the Skolt Sámi have combined different forms of livelihood for hundreds of years. In the old days, reindeer herding and fishing were the most important, but hunting, gathering, and lamb herding were significant too. Now the long era of combining forms of livelihood is coming rapidly to an end. Such traditional additional activities as fishing and berry picking have lost a great portion of their economic meaning for households, even though they are still among the traditional activities of the Skolt Sámi of Sevettijärvi Inari. At the same time, collaboration across lines of Skolt Sámi nuclear families has diminished, and Finns participate more than before in their livelihood activities. These are big changes from the perspective of Skolt Sámi tradition and culture.

As a general outcome of this study, I can state that the recognition of Skolt reindeer herders' changing work patterns could be used to support the construction of future Skolt Sámi culture. I hope that traditional elements of culture can be combined with modern cultural features so that the culture continues and its representatives can live good lives. The maintenance of culture requires plenty of work in the same way that the advancement of production does.

\section{REFERENCES}

Beach, Hugh. 1981. Reindeer-Herd Management in Transition: The Case of Tuorpon Saameby in Northern Sweden. Acta Universitatis Upsaliensis. Uppsala Studies in Cultural Anthropology 3. Uppsala: Uppsala University.

Bennet, John W. 1988. Introductory Essay. - Production and Autonomy. Anthropological Studies and Critiques of Development, edited by John W. Bennet and John R. Rowen. Lanham, MD: University Press of America, 1-39.

Begg, David; Stanley Fischer and Rudiger Dornbusch. 2005 [1984]. Economics. 8th edn. London: The McCraw-Hill Education.

Björklund, Ivar. 1990. Sámi Reindeer Pastoralism as an Indigenous Resource Management System in Norway: A Contribution to the Common Property Debate. - Development and Change 21 (1): 75- 86. DOI: https://doi.org/10.1111/j.1467-7660.1990.tb00368.x.

Ingold, Tim. 1976. The Skolt Lapps Today. Changing Cultures. Cambridge: Cambridge University Press.

Itkonen, Panu. 2012. Skolt Sámi Cooperation. Forms of Reciprocity in Work Situations of the Sevettijärvi Reindeer Herding Community at the Beginning of the $21^{\text {st }}$ Century and Actions of State Administration. Research Series in Anthropology. Helsinki: University of Helsinki. 
Lenstra, Menno. 1998. Saamen Met Rendieren. Nijmegen: Nijmegen University Press.

Linkola, Anni and Martti Linkola. 2000. Kolttasaamelaiset. The Skolt Sámi. Kuopio: the Sami Museum.

Paine, Robert. 1994. Herds of the Tundra. A Portrait of Saami Reindeer Pastoralism. Washington, DC: Smithsonian Institution Press.

Pelto, Pertti J. 1973. The Snowmobile Revolution: Technology and Social Change in the Arctic. Menlo Park, CA: Cummings Publishing Company.

Pennanen, Jukka. 2000. Jos ei ole poropaimenia, kansa häviää: Kuolan poronhoitajien sosiokulttuurinen adaptaatio 20. vuosisadalla. Helsinki: Suomalaisen Kirjallisuuden Seura.

Ruotsala, Helena. 2002. Muuttuvat palkiset. Elo, työ ja ympäristö Kittilän Kyrön paliskunnassa ja Kuolan Luujärven poronhoitokollektiiveissa vuosina 1930-1995. Kansatieteellinen Arkisto 49. Helsinki: Soumen Muinaismuistoyhdistys.

Sahlins, Marshall David. 2004 [1972]. Stone Age Economics. London: Routledge.

Ventsel, Aimar. 2005. Reindeer, Rodina and Reciprocity. Kinship and Property Relations in a Siberian Village. Halle Studies in the Anthropology of Eurasia 7. Münster: Lit Verlag.

Wonnacott, Paul and Ronald Wonnacot. 1990 [1979]. Economics. New York, NY: McGraw-Hill. 